\title{
ПРОГРАММНАЯ РЕАЛИЗАЦИЯ АЛГОРИТМОВ ОБРАБОТКИ ЗАІІУМЛЕННЫХ ДАННЫХ
}

\section{SOFTWARE IMPLEMENTATION OF NOISY DATA PROCESSING ALGORITHMS}

Евразийский национальный университет им. Л. Н. Гумилева, Казахстан / L. N. Gumilyov Eurasian National University, Kazakhstan

\begin{abstract}
B настоячее время существует большое число программных пакетов для сглаживания данньх (MatLab, Matетатica, Statistica). Целью данного исследования является програминая реализация набора наиболее эффективньх алгоритлов для тестовых исследований быстро меняющихся данных.
\end{abstract}

Клточевыс слова: сглаживание кривой, программное приложение, сигнал, данные.

Currently, there are a large number of software packages for data smoothing (MatLab, Matematica, Statistica). The purpose of this study is the software implementation of a set of the most effective algorithms for test studies of rapidly changing data.

Key words: curve smoothing, software application, signal, data.

Introduction. Modern information technology allows you to process and store virtually unlimited amounts of information. One type of such information is digital signals obtained, for example, as a result of experiments with video or audio equipment. Very often, these digital signals contain stepwise (spasmodic) changes that "clog" the information that is useful for analysis. Anti-aliasing is a technology used to eliminate the effect of "stepping" that occurs at the edges of a multitude of separate flat or three-dimensional images that are simultaneously displayed on the screen. Smoothing was invented in 1972 at the Massachusetts Institute of Technology in the Architecture Machine Group, which later became the main part of the Media Lab.

Curve smoothing algorithms are widely used in various studies. For example, Govindarajulu, Malloy, Ganguli, Spiegelman and Eisen [1] consider anti-aliasing techniques for modeling environmental epidemiological data. Astafiev, Shchedrin, and Yanusova in [2] proposed smoothing as a method that improves the process of convergence of curves with sharp changes in elevation. And Bocharov in [3] applied some smoothing algorithms to solve the problems of predicting the natural regime of the groundwater level. The analysis presented in the above works was carried out using various mathematical models. The construction of smoothed curves in these works was carried out using highly specialized software applications that are applicable only in these specific studies.

The purpose of this study is to develop and describe a software application that allows you to build a smoothed version of the measured data by some of the most relevant algorithms.

Methods. To develop the SCA software application (Smoothing Curve Application), the MS Visual Studio 2015 software application development environment was used (Figure 1).

Type of application - Windows Forms. Windows Forms allows you to implement a graphical user interface and is part of the Microsoft.NET Framework. It allows you to write traditional GUI applications with windows, forms. This approach simplifies access to Microsoft Windows interface elements by creating a wrapper for the Win32 API in managed code.

The main component used for plotting was the ZedGraph component. ZedGraph is a class library, user control, and web control for .NET written in C \# to draw 2D line, line, and pie charts. It has full capabilities for detailed settings, but most options have default settings for ease of use [4]. 


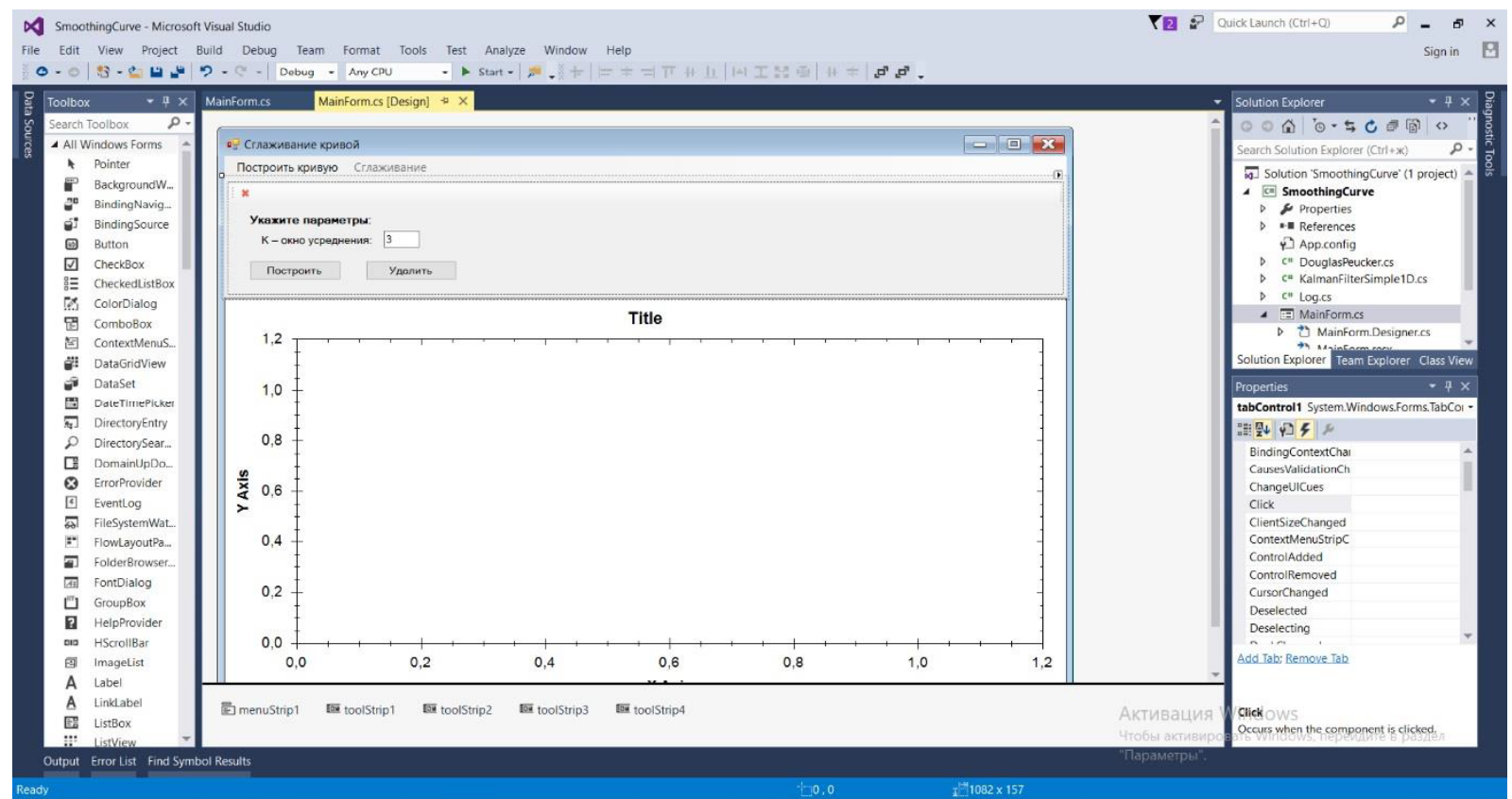

Fig. 1. MS Visual Studio 2015 interface

The programming language used to write the application code is $\mathrm{C}$ \#. C \# belongs to a family of languages with C-like syntax, of which its syntax is closest to $\mathrm{C}++$ and Java. The language has static typing, supports polymorphism, operator overloading (including explicit and implicit type conversion operators), delegates, attributes, events, properties, generalized types and methods, iterators, anonymous functions with support for closures, LINQ, exceptions, comments in the format XML [5].

Results. Figure 2 shows the main window of the developed SCA software application.

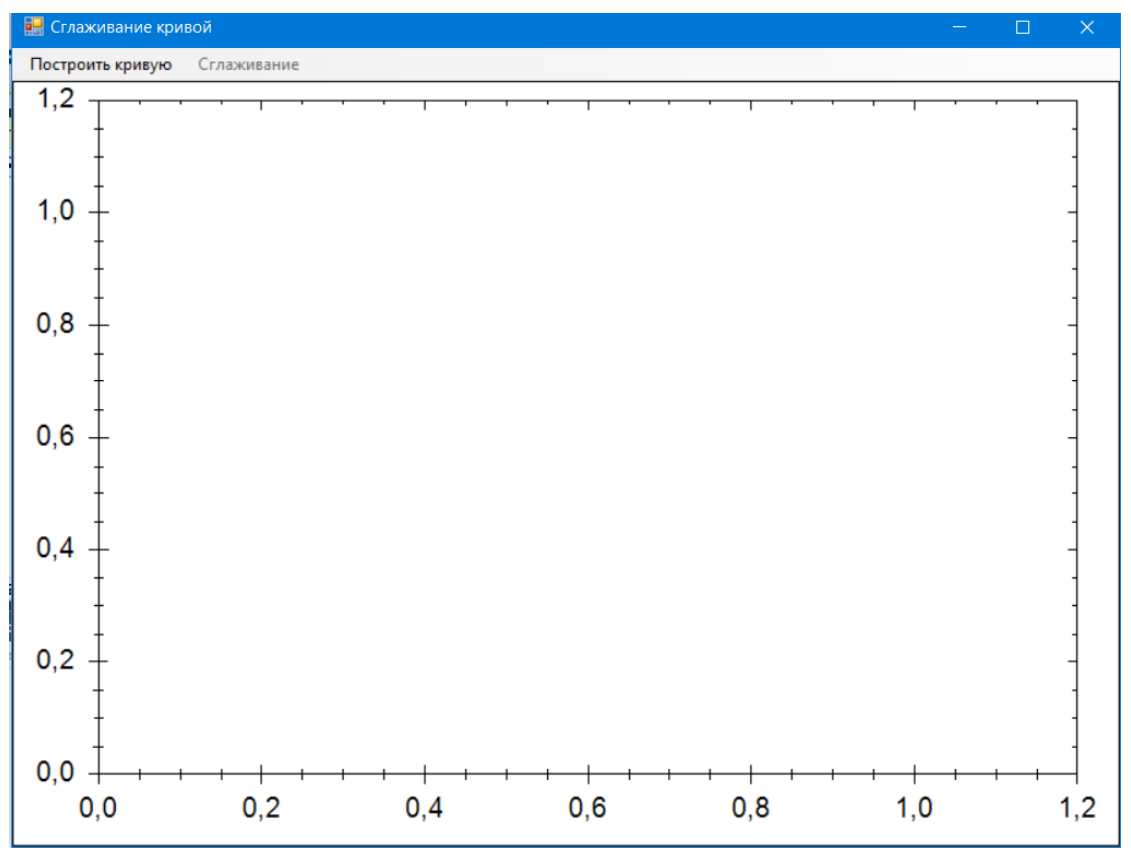

Fig. 2. SCA application interface

The main window contains the program menu and the workspace for graphing. The menu allows you to build a curve based on data obtained from a file or from a device (Figure 3). 


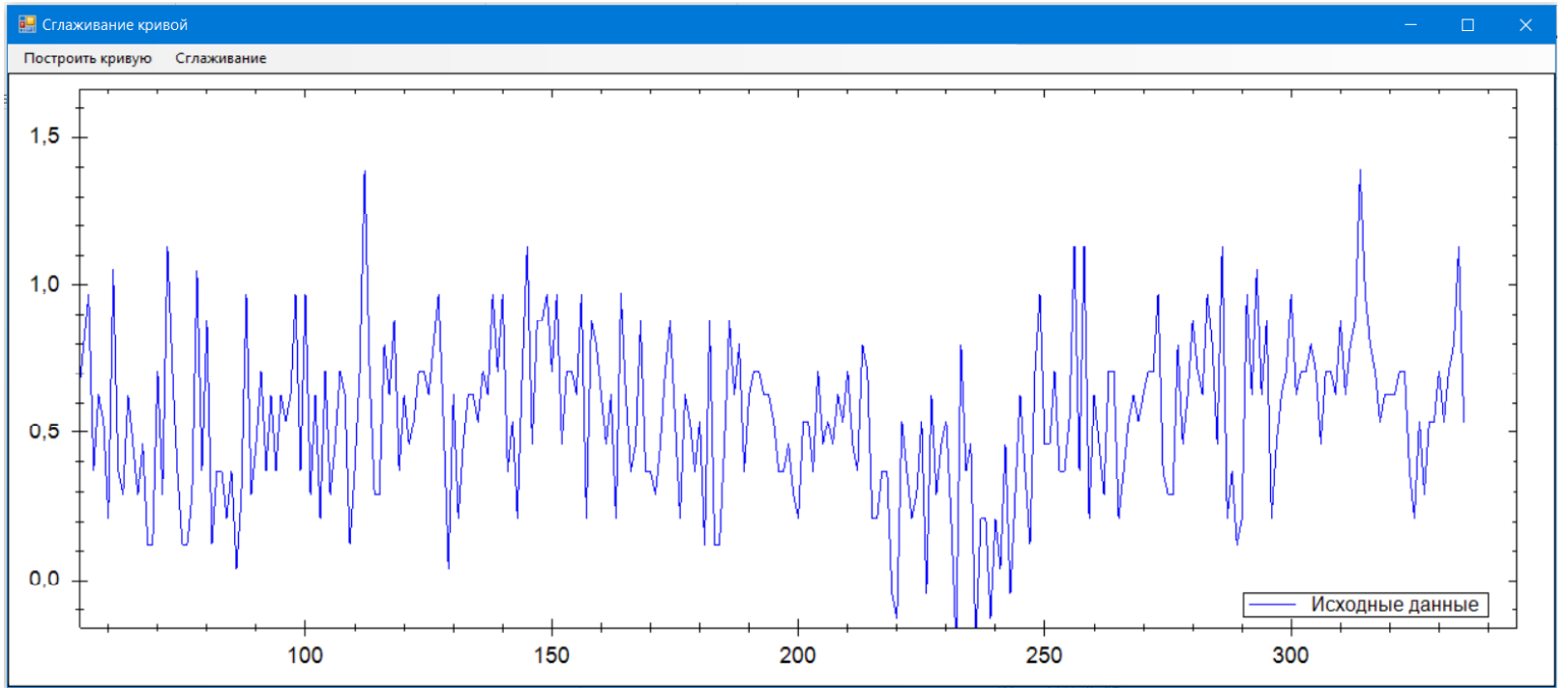

Fig. 3. Curve construction

After the graph is built, access to the Smoothing menu item is opened, which allows you to apply 4 types of smoothing:

1) according to Kalman;

2) low pass filter;

3) Douglas-Pecker algorithm;

4) moving average.

After specifying the necessary parameters on the graph, a curve is constructed that is obtained by the corresponding smoothing algorithm (Figure 4).

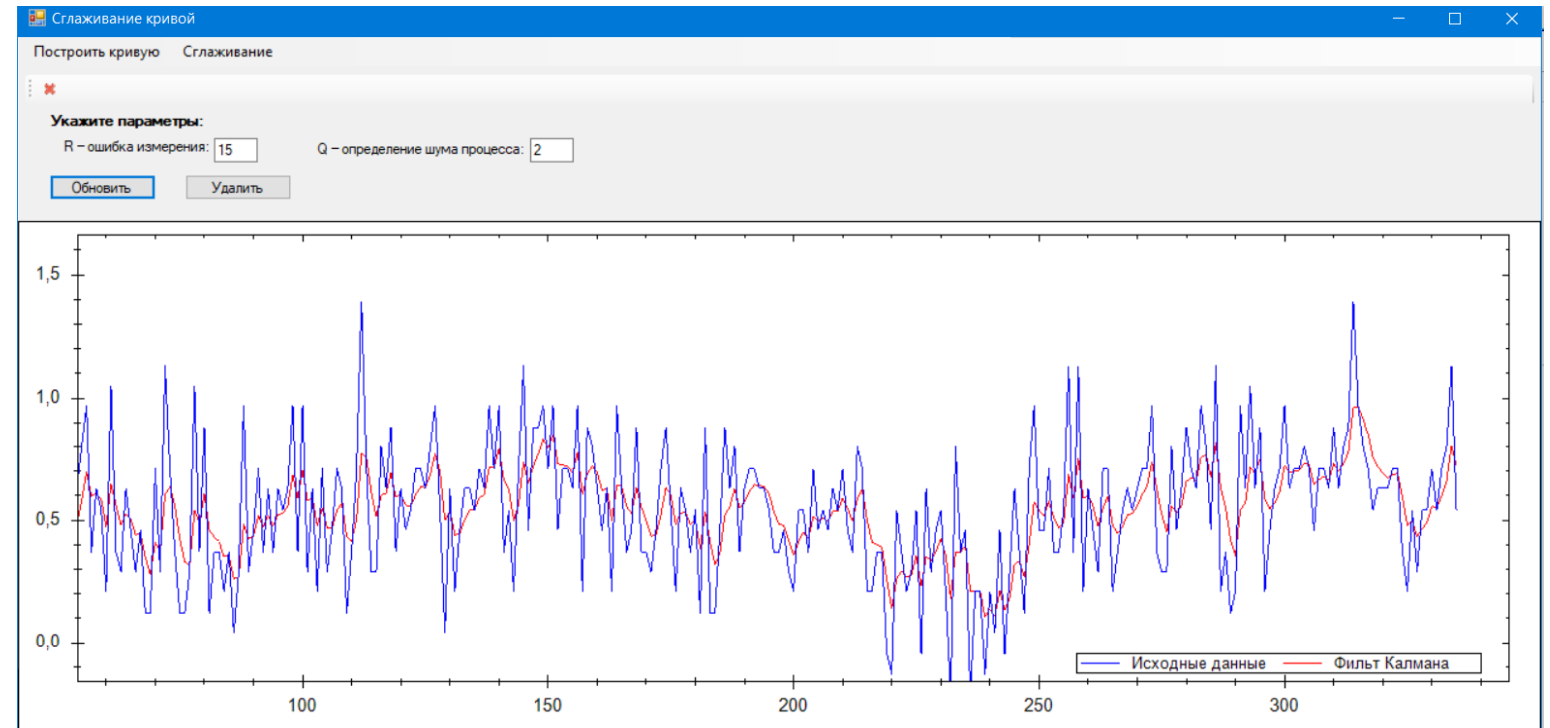

Fig. 4. Adding a smoothing curve

The SCA program allows you to simultaneously apply several types of smoothing for one curve, which in turn leads to the possibility of choosing the most optimal solution to the problem.

For a more detailed consideration of the curve, the program has a scaling function (Figure 5). 


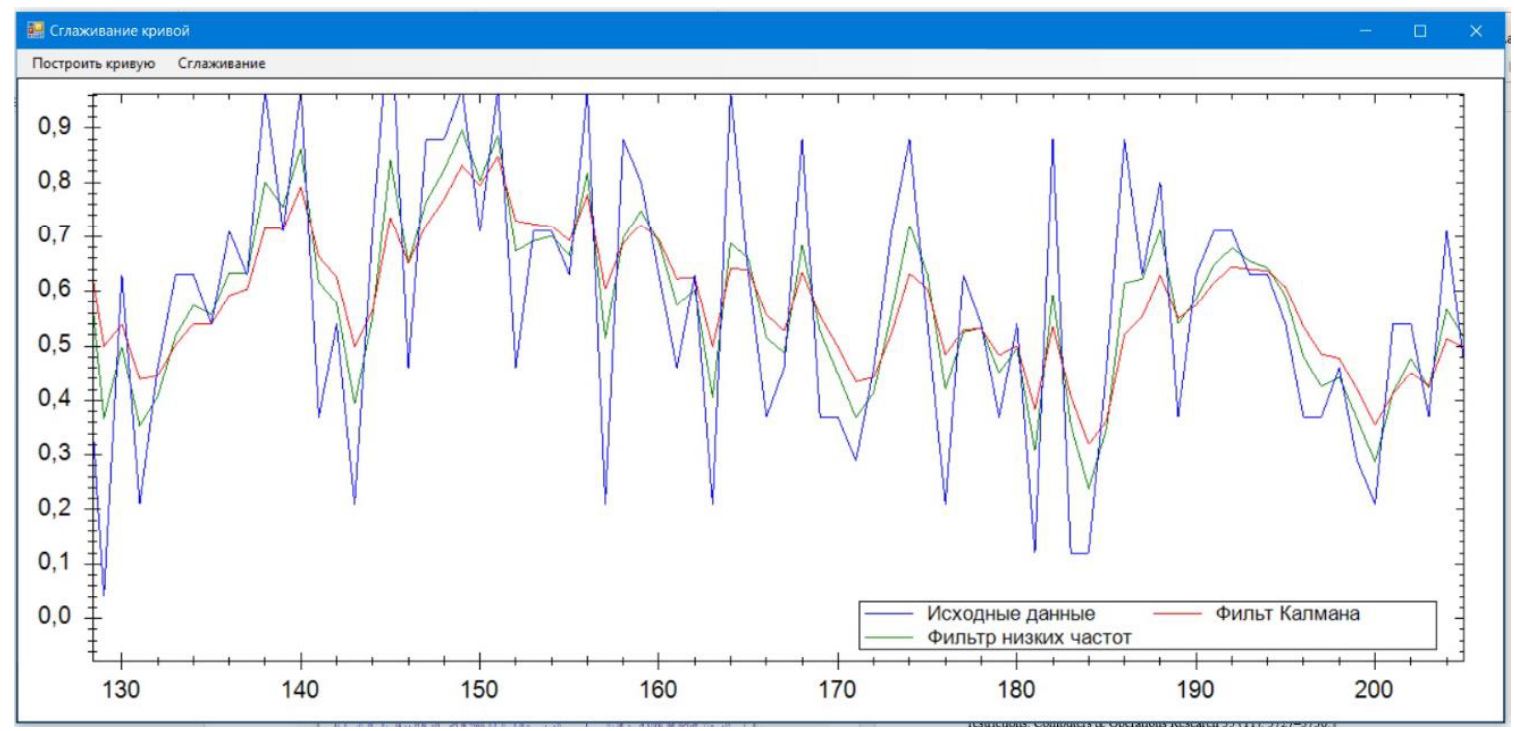

Fig. 5. Data scaling

If it is necessary to change the smoothing parameters, it is possible to update the smoothing curves or delete them.

Discussion and conclusions. The result of this work is the development of the SCA software application, which allows you to apply some algorithms for smoothing the curves obtained during the experiments. To develop a software application, the MS Visual Studio 2015 software application development environment and the C \# programming language were used.

This software package uses the main existing types of data smoothing, has an intuitive interface and can be a good tool for conducting research in the field of mathematical processing of results.

For example, the use of averaging of GPS navigation data for unmanned systems by the Kalman algorithm made it possible to effectively control the course of a lethal object. The gusts of wind that had taken off the UAV course were detected by the system, analyzed and transferred to the control system for course correction. Whereas the shortterm scatter of absolute altitude data according to GPS data associated with the measurement error (up to 4 meters with a duration of up to 100 milliseconds) was filtered and smoothed.

\section{ЛИТЕРАТУРА}

1. Govindarajulu US, Malloy EJ, Ganguli B, Spiegelman D, Eisen EA. The comparison of alternative smoothing methods for fitting non-linear exposure-response relationships with Cox models in a simulation study// Int J Biostat.-2009 - 5(1).

2. Астафьев С.Б., Щедрин Б.М., Янусова Л.Г. Сглаживание кривой интенсивности рассеяния для улучшения сходимости метода сближения растетных и экспериментальных кривых// Журнал «Поверхность. рентгеновские, синхротронные и нейтронные исследования». 2004. -№ 10. С. 39-45.

3. Бочаров В.Л. Применение метода интегральных кривых и сглаживания для прогноза естественного режима уровня грунтовых вод // Материалы региональной научно-практической конференции «Современные Проблемы И Опыт Гидрогеологических, Инженерно-Геологических И Эколого-Геологических Исследований На Территории ЦентральноЧерноземного Региона»: Издательско-полиграфический центр "Научная книга", Воронеж, 2018.

4. http://sourceforge.net/projects/zedgraph/ СпГ.: 2012

5. Лжеффри Рихтер "CLR via C\#. Программирование на платформе .NET Framework 4.5 на языке C\#". Питер -

6. Мальков Д.Н., Лихтин В.В. Сглаживание результатов измерений// Научно-техническое и экономическое сотрудничество стран АТР в XXI веке. 2011. Том 3. С. 199-206.

7. Батищев В. И. Принципы построения стабильных регуляризованных фильтров Калмана // Вестн. Сам. гос. техн. ун-та. Сер.: Физ.-мат. науки. 2000. №9.

8. Бладыко ІО. В. Сглаживающие фильтры // Энергетика. Известия высших учебных заведений и энергетических объединений СІПГ. 2010. №2.

9. Urs Ramer, «An iterative procedure for the polygonal approximation of plane curves»// Computer Graphics and Image Processing. 1972. 1(3) C. 244-256.

10. Сарычев Виктор Владимирович Оценка эффективности сглаживания сигнала по регулярным и нерегулярным отсчетам // Известия ІОФУ. Технические науки. 2009. №1.

\section{REFERENCES}

1. Govindarajulu US, Malloy EJ, Ganguli B, Spiegelman D, Eisen EA. For a non-linear exposure-to-study, smoothing methods for non-linear exposure study, Int j Biostat. 2009. 5 (1). 
2. Astaf'ev S.B., SHCHedrin B.M., YAnusova L.G. Sglazhivanie krivoj intensivnosti rasseyaniya dlya uluchsheniya skhodimosti metoda sblizheniya raschetnyh $\mathrm{i}$ eksperimental'nyh krivyh// ZHurnal «Poverhnost'. rentgenovskie, sinhrotronnye $\mathrm{i}$ nejtronnye issledovaniya». 2004. № 10. S. 39-45.

3. Bocharov V.L. Primenenie metoda integral'nyh krivyh i sglazhivaniya dlya prognoza estestvennogo rezhima urovnya gruntovyh vod// Materialy regional'noj nauchno-prakticheskoj konferencii «Sovremennye Problemy I Opyt Gidrogeologicheskih, Inzhenerno-Geologicheskih I Ekologo-Geologicheskih Issledovanij Na Territorii Central'no-Chernozemnogo Regiona»: Izdatel'skopoligraficheskij centr "Nauchnaya kniga", Voronezh, 2018.

4. http://sourceforge.net/projects/zedgraph/

5. Jeffrey Richter "CLR via C \#. Programming on the .NET Framework 4.5 in C \#." Peter - St. Petersburg: 2012.

6. Mal'kov D.N., Lihtin V.V. Sglazhivanie rezul'tatov izmerenij// Nauchno-tekhnicheskoe i ekonomicheskoe sotrudnichestvo stran ATR v XXI veke. 2011. Tom 3. S. 199-206.

7. Batishchev V. I. Principy postroeniya stabil'nyh regulyarizovannyh fil'trov Kalmana // Vestn. Sam. gos. tekhn. un-ta. Ser.: Fiz.-mat. nauki. 2000. №9.

8. Bladyko YU. V. Sglazhivayushchie fil'try // Energetika. Izvestiya vysshih uchebnyh zavedenij i energeticheskih ob"edinenij SNG. 2010 №2.

9. Urs Ramer, "An iterative procedure for the polygonal approximation of plane curves"// Computer Graphics and Image Processing. 1972. 1 (3). p. 244-256.

10. Sarychev Viktor Vladimirovich Ocenka effektivnosti sglazhivaniya signala po regulyarnym i neregulyarnym otschetam // Izvestiya YUFU. Tekhnicheskie nauki. 2009. №1.

\section{OБ ABTOPAX | ABOUT AUTHORS}

Атанов Сабыржан Кубейсинович, Евразийский национальный университет им. Л.І. Гумилева, доктор технических паук, профессор кафедры Вычислительной техники, тел.: +7-701-343-53-53, e-mail: atanov5@mail.ru

Atanov Sabyrzhan Kubejseinovich, L.N. Gumilyov Eurasian National University, Doctor of Technical Sciences, Professor of the Computer Engineering Department, phone: + 7-701-343-53-53, e-mail: atanov5@mail.ru

Муканова Жанна Аскаровна, Евразийский национальный университет им. Л.Н. Гумилева, докторант $\mathrm{PhD}$ по специальности «Вычислительная техника и программное обеспечение», тел.: +7-701-735-64-43, e-mail: zhanna.mukanova.83@mail.ru

Mukanova Zhanna Askarovna, L.N. Gumilyov Eurasian National University, PhD doctoral of the specialty «Computing and Software», phone: +7-701-735-64-43, e-mail: zhanna.mukanova.83@mail.ru 